第 65 巻第 6 号 岩石鉱物鉱床学会誌 1971 年 6 月 5 日

研究報文

\title{
BASIC AND INTERMEDIATE VOLCANIC ROCKS FROM THE PALEOZOIC FORMATIONS IN THE SOUTHERN KITAKAMI MOUNTAINLAND, JAPAN
}

\author{
SATOSHI Kanisawa \\ Department of Earth Science, College of Ants and Sciences, \\ Tohoku University, Sendai. Japan
}

\section{INTRODUCTION}

There are abundant volcanic rocks and their pyroclastics intercalated in the Paleozoic formations in the Southern Kitakami mountainland. Petrological characteristics of these rocks are very important from the viewpoint of petrographic province and the succession of igneous activity in the Paleozoic era. Since they suffered low grade metamorphism or alteration and most of their primary minerals were transformed into various kinds of lowtemperature metamorphic minerals, however, they have not been paid much attention by igneous petrologists.

Recently, the studies of the Paleozoic volcanic rocks in the Central and the Southwest Japan have been carried out, with special reference to chemical characteristics (Tanaka, 1970; Hashimoto, Kashima and Saito, 1970).

In the present paper, the petrographic characteristics of the volcanic rocks in this district and their chemical features are described from the standpoint of igneous petrology.

The author wishes to express his thanks to Professor Kenzo Yagi of the Hokkaido University for critical reading of the manuscript and many suggestions. Thanks are also due to Assistant Professor Ken-ichiro Aoki and Assistant Professor Keiji Oide of the Tohoku University for thier valuable advices. The author is also indebted to Dr. Masafumi Murata of the Tohoku University and Mr. Yosuke Fujioka of the Nippon Mining Co. for providing the rock specimens and useful suggestions.

(Manuscript received march 26, 1971) 


\section{PETROGRAPHY OF VOLGANIG ROCKS}

In the Southern Kitakami mountainland, many products of basic and intermediate volcanism are intercalated in various horizons of the Paleozoic formations. Especially, the Motai Group belonging to the pre-Upper Devonian, the Arisu and the Ohdaira Formations belonging to the lower Carboniferous and the Ubaishi Formation in the middle Permian consist of large amounts of lavas, sheets and pyroclastics. Their stratigraphic successions are shown in Table 1.

It is clear from the petrological investigations that the rocks of the Motai Group suffered glaucophanitic metamorphism, containing alkali-amphiboles, pumpellyite, epidote, albite, actinolite and chlorite in the basic rocks (Kanisawa, 1964). Description of the Motai Group is not given here to prevent repetition.

The lower Carboniferous is divided into three formations, namely, the Hikoroichi, Arisu and Ohdaira Formations. The Hikoroichi Formation consists mainly of slate and dacitic tuff. Rocks of volcanic origin in the lower part are dacitic tuff containing idiomorphic to hypidiomorphic plagioclase, quartz and fragments of dacite or andesite. In the middle part of the Hikoroichi Formation, dacite or dacitic tuff is main component and contains plagioclase $\left(\mathrm{An}_{34-32}\right)$ and corroded quartz. Andesitic breccia is often present.

Table 1. Stratigraphic succession of the Paleozoic formations in the Southern Kitakami mountainland. (mainly according to Onuki $(1969)^{*}$ )

\begin{tabular}{|c|c|c|}
\hline \multirow{2}{*}{ Permian } & Ubaishi f."* & Kanokura $f$ \\
\hline & & Sakamotozawa f. \\
\hline \multirow{5}{*}{ Carboniferous } & \multicolumn{2}{|c|}{ Nagaiwa f. } \\
\hline & \multicolumn{2}{|c|}{ Onimaru f. } \\
\hline & \multicolumn{2}{|c|}{ Ohdaira f. } \\
\hline & \multicolumn{2}{|c|}{ Arisu f." } \\
\hline & \multicolumn{2}{|c|}{ Hikoroichi f. } \\
\hline \multirow[b]{2}{*}{ Devonian } & Tobigamori f. & \\
\hline & Motai $\underset{\substack{\downarrow \\
?}}{\text { Group }}$ & $\begin{array}{l}\text { Ohmori f. } \\
\text { Nakazato f. } \\
\text { Ohnof. }\end{array}$ \\
\hline
\end{tabular}

* Stratigraphic reexamination is being carried by Murata.

** Dominat basic or intermediate volcanism. 
In the upper part of the Hikoroichi Formation, dacitic tuff is more abundant than andesitic tuff. Chlorite, sericite, calcite, leucoxene and albite are the secondary minerals. Plagioclase is relic andesine of high temperature form or secondary pure albite of low temperature form. In the Arisu Formation, the lower part contains dacitic and andesitic tuff. Quartz and lithic fragments are included in dacitic tuff, and clinopyroxene in andesitic tuff. The middle part of the Arisu Formation consists mainly of basaltic rocks and their tuffs, which contain relic clinopyroxene and plagioclase. Most plagioclases were inverted to low-temperature albite. In these basic rocks, actinolite, chlorite, epidote, calcite, leucoxene and pumpellyite (?) are observed as the secondary minerals. Frequently, chlorite and iddingsite pseudomorphs after olivine or orthopyroxene exist. In the upper part of the Arisu Formation, dacitic tuff which contains fragmental crystals of primary quartz and plagioclase is dominant with subordinate amount of andesitic tuff. These rocks contain secondary minerals such as sericite, chlorite, epidote, actinolite, leucoxene, calcite and stilpnomelane (?). The basal part of the Ohdaira Formation consists of dacitic tuff including fragmental plagioclase and andesite breccia. In the lower part of the Ohdaira Formation, basaltic and andesitic rocks associated with their tuffs are dominant. Because the area covered by the Ohdaira Formation suffered extensive contact metamorphism by the Kesengawa granodiorite, detailed petrographical characters can not be clarified. The Permian Ubaishi Formation is mainly composed of andesitic to dacitic pyroclastics and lavas. This formation is correlated with the uppermost Sakamotozawa Formation to the Kanokura Formation by the fossil evidence (Murata and Maiya, 1964). Rock facies ranges from clinopyroxene andesite through clinopyroxene-hornblende andesite to dacite. Mafic minerals altered commonly to chlorite, calcite and actinolite, however porphyritic plagioclase retains primary high-temperature form with the composition of $\mathrm{An}_{\text {24-92. }}$. Detailed geological investigations of the lower Carboniferous to Permian of the Southern Kitakami mountainland were carried out by many workers and recently summarized by Onuki (1969).

Next, relic and recrystallized minerals of basic volcanic rocks will be described.

\section{1) Clinopyroxenes}

Basaltic rocks in the Arisu Formation contain large amounts of phenocrystic clinopyroxenes. Because there is no doubt that these clinopyroxenes did not recrystallized by secondary alteration but crystallized directly from magma, determination of their composition is very important to estimate the rock series of the host rocks. Optical variation of clinopyroxenes from the Arisu Formation has the range of $2 \mathrm{Vz}=43^{\circ} \sim 56^{\circ}$ and $\beta=1.694 \sim 1.703$. 
Table 2. Optical data of relic clinopyroxene of basalts in the Arisu Formation.

\begin{tabular}{|c|c|c|c|c|}
\hline Specimen No. & $2 \mathrm{Vz}$ & $c \Lambda Z$ & $\beta$ & $\begin{array}{c}\text { Estimated } \\
\text { composition }\end{array}$ \\
\hline $69729-5$ & $52^{\circ}$ & n.d. & 1.694 & $\mathrm{En}_{38} \mathrm{Fs}_{\mathrm{S}_{19}} \mathrm{Wo}_{43}$ \\
\hline $697,30-3$ & $\begin{array}{l}50^{\circ}-47.5^{\circ} \\
\text { average } 49^{\circ}\end{array}$ & $41^{\circ}$ & 1.697 & $\mathrm{En}_{37} \mathrm{FS}_{23} \mathrm{Wo}_{40}$ \\
\hline $6909060 \mathrm{i}$ & $\begin{array}{l}54^{\circ}-45.5^{\circ} \\
\text { average } 52^{\circ}\end{array}$ & $38.5^{\circ}$ & 1.696 & $\mathrm{En}_{37} \mathrm{Fs}_{21} \mathrm{~W}_{0_{42}}$ \\
\hline 69090607 & $\begin{array}{l}52^{\circ}-45^{\circ} \\
\text { zoned crystal } \\
\text { core } 49.5^{\circ} 48.5^{\circ} \\
\text { rim } 45^{\circ} 44.5^{\circ} \\
\text { average of core } 48.5^{\circ}\end{array}$ & $40^{\circ}$ & 1.696 & $\mathrm{En}_{38} \mathrm{Fs}_{s_{22}} \mathrm{~W}_{0_{40}}$ \\
\hline $69913-1$ & $\begin{array}{l}54^{\circ}-52^{\circ} \\
\text { average } 53^{\circ}\end{array}$ & $37.5^{\circ}$ & 1.703 & $E_{n_{31}} F_{s_{26}} W_{0,3}$ \\
\hline $69913-3$ & $\begin{array}{l}47^{\circ}-43^{\circ} \\
\text { average } 45^{\circ}\end{array}$ & $39^{\circ}$ & 1.703 & $\begin{array}{l}\mathrm{E}_{34,5} F_{S_{29,5}} \\
W_{0_{43}}\end{array}$ \\
\hline $69913-6$ & $\begin{array}{l}56^{\circ}-52^{\circ} \\
\text { average } 55^{\circ}\end{array}$ & n.d. & 1.698 & $\begin{array}{l}\mathrm{En}_{33.5} \mathrm{Fs}_{21.5} \\
\mathrm{Wo}_{0_{45}}\end{array}$ \\
\hline
\end{tabular}

$2 \mathrm{Vz}$ of zoned crystal has larger value in the core and ranges smaller to the margin. Simple twinning on (100) is common. Optical properties of these clinopyroxenes are shown in Table 2, with composition estimated from the diagram by Hess (1949) and Muir (1951). The relic clinopyroxenes from the Arisu Formation range from salite to salitic augite in composition.

2) Plagioclase

Plagioclase is the most common mineral throughout the lower Carboniferous and the Permian volcanics. Dacite, andesite and tuff contains idiomorphic to hypidiomorphic crystals which show sometimes zonal structure and twinning. Most crystals are dusty, but some of them are clear. In the clinopyroxene basalt from the Arisu Formation, plagioclase exists only in the groundmass or as microphenocrysts.

Microscopic determinations by a universal stage reveal the grade of alteration and structural state of plagioclase. Köhler angles $\mathrm{XX}, \mathrm{YY}$ and $\mathrm{ZZ}$ of plagioclases twinned after albite law were measured on a universal stage and An content and ordering degree were determined using Uruno's (1963) diagram. By this diagram, An mol. \% and ordering degree can be read at once with an accuracy of $\pm \mathrm{An}_{2}$ and tordering degree 0.2 . Distinct contrast is observed between the lower Carboniferous and the Permian volcanics as shown in Fig.1. The greater part of plagioclases from the lower Carboniferous rocks were changed into pure albite with high ordering degree. It is noticeable that there is no visible gradation in composition between the 

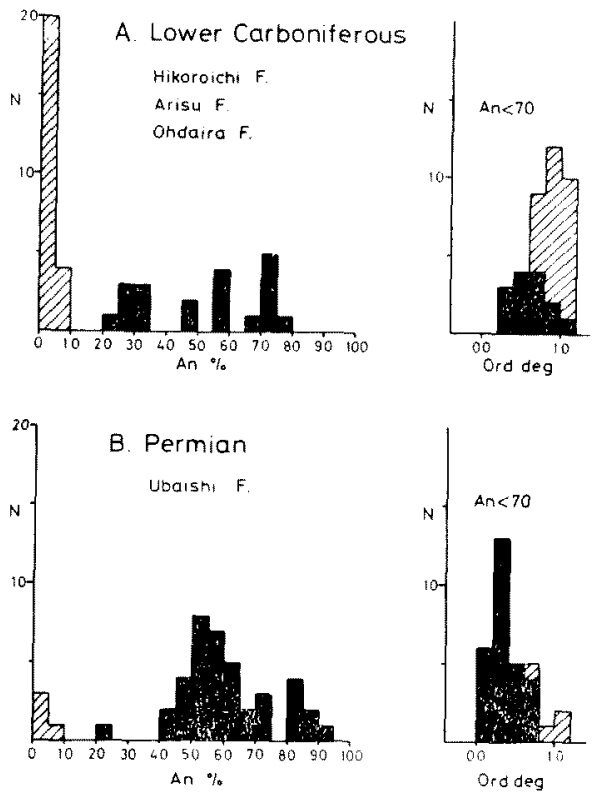

Fig. 1. Frequency distributions of plagioclase composition and ordering degree.

$\mathrm{N}$; number of measurement, Black; primary plagioclase, Shaded; secondary albite.

primary Ca-plagioclase and the secondary albite. Most secondary albite has composition less calcic than $\mathrm{An}_{5}$. Secondary albitization retains the original shapes of Ca-plagioclase, but show clouded and unzoned appearance. The clouded appearance of secondary albite contrasts with the clear primary $\mathrm{Ca}$ plagioclase. Ordering degree of secondary albite is higher than 0.6 , and thus secondary albite belongs to typical low temperature form. X-ray diffraction patterns of secondary albite show values of $\mathrm{CuK} \alpha 2 \theta(131-131)=1.17 \sim 1.37$. These values indicate low albite state, corresponding to optical data. Plagioclase from the rocks of the Permian Ubaishi Formation, on the other hand, retains original form with ordering degree of $0.2 \sim 0.4$ belonging to typical high temperature form. The compositional range of primary plagioclase is $\mathrm{An}_{29-92}$. Albitized specimen is rare and confined locally. Sericite and clay minerals occur along cracks and margin of crystal by secondary alteration.

3) Secondary minerals

Low Igrade metamorphic minerals are widely distributed in the lower 
Carboniferous rocks. Sericite-chlorite-calcite association in dacitic rocks and actinolite-epidote-chlorite-sericite-calcite-leucoxene association in basic rocks are common. Chlorite and actinolite are common in basic rocks. Actinolite occurs in the margins of relic clinopyroxenes and as separate crystals. Actinolites are nearly colourless to pale green and have $2 \mathrm{Vx}=70.5^{\circ} \sim$ $82^{\circ}, \quad \mathrm{c} \wedge \mathrm{Z}=13^{\circ} \sim 17^{\circ}$, and $\mathrm{b}=\mathrm{Y}$ - and $\mathrm{C}$-axes in common with associated clinopyroxenes.

Common secondary minerals in the Permian Ubaishi Formation are sericite, calcite, chlorite and leucoxene with subordinate amounts of actinolite and epidote.

From the evidence mentioned above, mineral assemblages of basic volcanic rocks of the lower Carboniferous belong to greenschist facies. The mineral assemblages of the Ubaishi Formation, on the other hand, may correspond to zeolite facies or prehnite-pumpellyite facies, but there is no positive evidence for this because of the absence of any critical Ca-Al silicates such as zeolite, prehnite or pumpellyite. The absence of any critical minerals in the Ubaishi Formation may be due to the lack in rocks of suitable chemical composition or due to the effects of difference of $\mathrm{H}_{2} \mathrm{O}$ and $\mathrm{CO}_{2}$.

\section{ALBITISATION OF PLAGIOCLASE}

Volcanic rocks contain usually high temperature plagioclase. These high temperature plagioclases have been changed to some extent into more sodic plagioclase which is generally considered to be albite by the process of low grade metamorphism or hydrothermal alteration. However, conclusive data on this point are insufficient at present. Some examples of secondary albitization in volcanic rocks are reported by Dickinson (1962), Lidiak (1965) and Jolly (1970). Dickinson decsribed albitization $\left(\mathrm{An}_{0-6}\right)$ of Ca-plagioclase accompanied by formation of several hydrous Ca-bearing phases from the Jurassic andesitic strata in Central Oregon. The spacial pattern of albitization shows no consistent relation to stratigraphic or structural position. According to Lidiak, secondary albite showing low-intermediate state by optical and $\mathrm{X}$-ray measurements occurs in some spilitic rocks from North-Central Puerto Rico. Plagioclases in volcanic rocks of late Cretaceous in South-Central Puerto Rico are partially or completely albitized during zeolite and prehnitepumpellyite facies metamorphism, and their composition is less calcic than $\mathrm{An}_{6}$, showing low or intermediate structure. There is no visible gradation in composition between the primary Ca-plagioclase and secondary albite (Jolly, $1970)$.

Plagioclases of rocks of the lower Carboniferous show the identical characters with those of the above mentioned districts, namely: most secondary- 
albites of this district have composition less calcic than $\mathrm{An}_{6}$ and high ordering degree. In most of the tuffs and lavas, phenocrystic plagioclases are completely replaced by secondary albite, retaining primary shape with clouded appearance. Albitization is distinct in the lower Carboniferous rocks, but there is no visible relation between stratigraphical situation and albitization. Metasomatism during albitization in large scale did not exist, because of rather homogeneous chemical composition and poverty in $\mathrm{Na}_{2} \mathrm{O}$ in the Arisu Formation as shown in the following. Intrastratal exchange of substance, however, might have occurred in both microscopic and megascopic dimensions.

On the contrary, alteration process of plagioclases in propylites are different from those of low grade burial metamorphic rocks. According to Kim (1964) and Yoshitani (1970), secondary plagioclases in propylites from the green tuff regions of the Neogene Tertiary in Japan are not pure albite but oligoclase to andesine, showing high concentration of $\mathrm{An}_{\mathbf{2 2}}$. Moreover, Yoshitani described that the secondary plagioclases maintain the primary temperature state; that is, whether they belong to low temperature form or high temperature form, the optical type of the secondary plagioclases is just the same as that of the primary plagioclases. Although we cannot definitely explain these difference in the albitization process, these may be due to the difference of chemical potential of $\mathrm{Na}_{2} \mathrm{O}$ between hydrothermal alteration and burial metamorphism. From the hydrothermal synthesis of low albite, Martin (1969) suggested that the widespread occurrence of ordered albite is due to the common presence of persodic fluids permitted initially disordered albite to attain a fully ordered configuration at relatively low temperatures. This problem will be discussed in a future study.

\section{GHEMICAL COMPOSITION}

It is important to clarify the chemical composition of rocks in order to infer the parental magma of the Paleozoic volcanic rocks, and to estimate the nature of petrographic province. Since Paleozoic volcanic rocks commonly suffered low grade metamorphism, there is a problem that some kind of metasomatism might have existed. However, the nature of rocks will be discussed on the assumption that the bulk chemical composition have not been changed so much from original rocks. For this purpose, specimens for analysis were all prepared carefully from apparently homogeneous lavas or sheets, excluding those parts traversed by veins or networks of calcite, epidote etc. All the analyses were made by the ordinary wet method, the alkalies being determined by means of atomic absorption spectroscopy.

In total fifteen specimens were chemically analysed: seven from the Arisu

Formation, two from the Ohdaira Formation both belonging to the lower 
Table 3. Chemical analyses of volcanic rocks of the

\begin{tabular}{|c|c|c|c|c|c|c|c|}
\hline & 1 & 2 & 3 & 4 & 5 & 6 & 7 \\
\hline $\mathrm{SiO}_{2}$ & 47.75 & 49.03 & 49.47 & 51.12 & 51.44 & 51.88 & 52.68 \\
\hline $\mathrm{TiO}_{2}$ & 0.71 & 0.67 & 0.62 & 0.70 & 0.52 & 0.55 & 0.56 \\
\hline $\mathrm{Al}_{2} \mathrm{O}_{3}$ & 15.84 & 15.10 & 15.60 & 14.41 & 16.96 & 17.17 & 15.52 \\
\hline $\mathrm{Fe}_{2} \mathrm{O}_{3}$ & 2.98 & 3.37 & 3.26 & 1.32 & 3.32 & 2.38 & 2.67 \\
\hline $\mathrm{FeO}$ & 5.99 & 6.16 & 5.58 & 7.16 & 4.75 & 4.75 & 4.95 \\
\hline $\mathrm{MnO}$ & 0.15 & 0.15 & 0.15 & 0.12 & 0.14 & 0.11 & 0.13 \\
\hline $\mathrm{MgO}$ & 9.84 & 8.40 & 7.95 & 8.45 & 6.53 & 6.93 & 7.13 \\
\hline $\mathrm{CaO}$ & 10.26 & 10.87 & 11.74 & 6.90 & 10.43 & 9.37 & 11.21 \\
\hline $\mathrm{Na}_{2} \mathrm{O}$ & 1.41 & 1.57 & 1.98 & 4.49 & 2.35 & 2.97 & 2.33 \\
\hline $\mathrm{K}_{2} \mathrm{O}$ & 0.65 & 0.18 & 0.30 & 1.11 & 0.72 & 0.46 & 0.10 \\
\hline $\mathrm{H}_{2} \mathrm{O}+$ & 3.67 & 4.21 & 3.22 & 3.90 & 2.76 & 3.09 & 2.63 \\
\hline $\mathrm{H}_{2} \mathrm{O}-$ & 0.21 & 0.08 & 0.16 & 0.14 & 0.12 & 0.08 & 0.09 \\
\hline $\mathrm{P}_{2} \mathrm{O}_{5}$ & 0.06 & 0.06 & 0.04 & 0.07 & 0.05 & 0.06 & 0.06 \\
\hline Total & 99.52 & 99.85 & 100.07 & 99.89 & 100.09 & 99.80 & 100.06 \\
\hline $\mathrm{Q}$ & 0.41 & 4.33 & 2.24 & - & 4.44 & 2.84 & 6.49 \\
\hline C & - & - & - & - & - & - & - \\
\hline or & 3.84 & 1.06 & 1.78 & 6.56 & 4.28 & 2.72 & 0.61 \\
\hline$a b$ & 11.89 & 13.26 & 16.72 & 36.42 & 19.86 & 25.10 & 19.70 \\
\hline an & 34.94 & 33.58 & 32.75 & 15.87 & 33.55 & 32.11 & 31.55 \\
\hline $\mathrm{Ne}$ & - & - & - & 0.82 & - & - & - \\
\hline fwo & 6.52 & 8.35 & 10.53 & 7.47 & 7.46 & 5.86 & 9.91 \\
\hline Di en & 4.55 & 5.64 & 7.21 & 4.61 & 5.15 & 4.00 & 6.76 \\
\hline fs & 1.41 & 2.06 & 2.47 & 2.42 & 1.69 & 1.39 & 2.35 \\
\hline $\mathrm{Hy}\{\mathrm{en}$ & 20.05 & 15.36 & 12.67 & - & 11.18 & 13.33 & 11.07 \\
\hline${ }^{n y}$ fs & 6.22 & 5.62 & 4.32 & - & 3.68 & 4.65 & 3.84 \\
\hline Ol $\{$ fo & - & 一 & - & 11.56 & - & - & - \\
\hline $\int_{\mathrm{fa}}$ & - & - & - & 6.71 & - & - & - \\
\hline $\mathrm{Mt}$ & 4.32 & 4.90 & 4.73 & 1.93 & 4.83 & 3.46 & 3.87 \\
\hline Il & 1.35 & 1.28 & 1.19 & 1.34 & 0.98 & 1.05 & 1.06 \\
\hline Ap & 0.13 & 0.13 & 0.10 & 0.17 & 0.13 & 0.13 & 0.13 \\
\hline
\end{tabular}

Carboniferous, and six from the Permian Ubaishi Formation. The petrographic descriptions of the analysed rocks are given in Appendix. The results of chemical analyses are listed in Table 3 . In Table 3, Nos. $1 \sim 7$ are rocks of the Arisu Formation, Nos. 8 and 9 the Ohdaira Formation, and Nos.10 15 the Ubaishi Formation.

As shown in the Table, the composition of analysed rocks from the lower Carboniferous of the Southern Kitakami mountainland are all basaltic. No. 
Paleozoic volcanic rocks in the Kitakami Mountainland

Paleozoic formations, Southern Kitakami mountainland.

\begin{tabular}{|c|c|c|c|c|c|c|c|}
\hline 8 & 9 & 10 & 11 & 12 & 13 & 14 & 15 \\
\hline 50.01 & 51.47 & 49.55 & 50.45 & 52.52 & 53.86 & 58.25 & 66.30 \\
\hline 2.22 & 0.51 & 1.00 & 1.62 & 1.50 & 0.73 & 0.58 & 0.35 \\
\hline 15.45 & 17.00 & 17.89 & 17.37 & 17.08 & 15.17 & 17.23 & 17.76 \\
\hline 1.54 & 2.05 & 2.00 & 3.07 & 2.88 & 1.03 & 1.61 & 0.93 \\
\hline 10.85 & 6.26 & 6.87 & 6.67 & 6.60 & 5.59 & 4.49 & 2.87 \\
\hline 0.32 & 0.13 & 0.15 & 0.17 & 0.17 & 0.11 & 0.10 & 0.06 \\
\hline 4.50 & 7.23 & 3.76 & 2.96 & 3.85 & 7.89 & 2.33 & 0.12 \\
\hline 8.83 & 10.53 & 8.15 & 6.81 & 7.66 & 7.43 & 6.54 & 0.93 \\
\hline 4.53 & 2.03 & 3.18 & 4.64 & 3.67 & 4.41 & 4.63 & 5.86 \\
\hline 0.26 & 0.44 & 0.49 & 1.23 & 1.13 & 1.25 & 0.74 & 1.71 \\
\hline 1.37 & 2.14 & 6.63 & 4.45 & 2.50 & 2.44 & 3.33 & 3.12 \\
\hline 0.07 & 0.03 & 0.11 & 0.17 & 0.20 & 0.13 & 0.10 & 0.19 \\
\hline 0.07 & 0.05 & 0.13 & 0.36 & 0.25 & 0.21 & 0.16 & 0.17 \\
\hline 100.02 & 99.87 & 99.91 & 99.97 & 100.01 & 100.24 & 100.09 & 100.37 \\
\hline- & 4.03 & 3.53 & - & 4.04 & - & 10.27 & 22.21 \\
\hline- & - & - & - & - & - & - & 4.98 \\
\hline 1.56 & 2.61 & 2.89 & 7.28 & 6.67 & 7.39 & 4.39 & 10.12 \\
\hline 37.15 & 17.13 & 26.88 & 39.20 & 31.02 & 37.26 & 39.14 & 49.52 \\
\hline 21.02 & 35.95 & 33.05 & 22.91 & 26.77 & 17.88 & 23.99 & 3.50 \\
\hline 0.62 & - & - & - & - & - & - & - \\
\hline 9.33 & 6.66 & 2.74 & 3.58 & 4.00 & 7.35 & 3.11 & - \\
\hline 3.93 & 4.15 & 1.33 & 1.77 & 2.16 & 4.69 & 1.49 & - \\
\hline 5.43 & 2.10 & 1.36 & 1.74 & 1.70 & 2.18 & 1.57 & -- \\
\hline- & 13.93 & 8.07 & 4.28 & 7.47 & 5.63 & 4.34 & 0.30 \\
\hline- & 7.08 & 8.21 & 4.25 & 5.86 & 2.38 & 4.55 & 4.03 \\
\hline 5.12 & - & - & 0.94 & - & 6.58 & - & - \\
\hline 7.83 & - & - & 1.04 & $\rightarrow$ & 2.98 & - & - \\
\hline 2.23 & 2.97 & 2.90 & 4.45 & 4.18 & 1.48 & 2.34 & 1.35 \\
\hline 4.23 & 0.97 & 1.90 & 3.09 & 2.86 & 1.38 & 1.11 & 0.67 \\
\hline 0.17 & 0.13 & 0.30 & 0.84 & 0.60 & 0.50 & 0.37 & 0.40 \\
\hline
\end{tabular}

4 of the Arisu Formation and No.8 of the Ohdaira Formation are richer in $\mathrm{Na}_{2} \mathrm{O}$ than other basalts. Especially, No.4 may be called spilite from chemical composition and the mineral paragenesis. Basaltic rocks of the Arisu Formation except $\mathrm{No} .4$ are low in alkalies, $\mathrm{TiO}_{2}$ and $\mathrm{P}_{2} \mathrm{O}_{5}$, being rather tholeiitic. No.9 of the Ohdaira Formation has composition similar to that of the Arisu Formation. The CIPW normative compsition of the Arisu and the Ohdaira Formations, except No.4 and 8 , has $\mathrm{Q}+\mathrm{Hy}$, but Nos.4 and 8 contain $\mathrm{O} 1+\mathrm{Ne}$. 

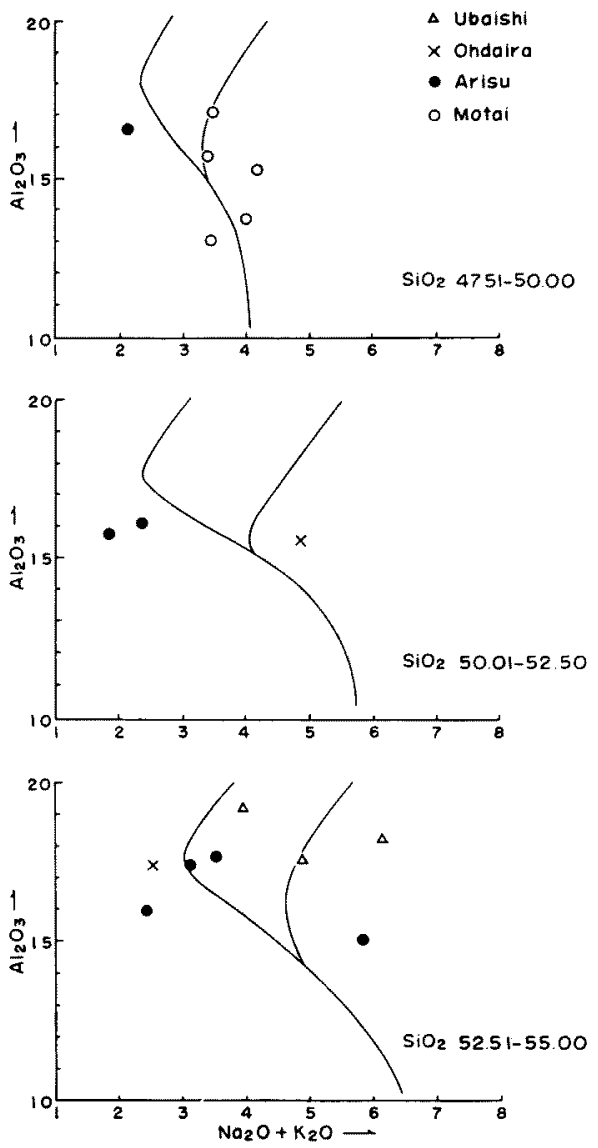

Fig. 2. $\mathrm{Al}_{2} \mathrm{O}_{3}-\left(\mathrm{Na}_{2} \mathrm{O}+\mathrm{K}_{2} \mathrm{O}\right)-\mathrm{SiO}_{2}$ diagram of Paleozoic volcanic rocks from the Southern Kitakami mountainland.

The composition of rocks of the Permian Ubaishi Formation has a wide range from basaltic andesite to dacite. Commonly, they are high in $\mathrm{Al}_{2} \mathrm{O}_{3}$ and alkalies, but have no normative nepheline.

Kuno (1960) proposed the classification of rock series by chemical composition on the basis of $\mathrm{Al}_{2} \mathrm{O}_{3}-\left(\mathrm{Na}_{2} \mathrm{O}+\mathrm{K}_{2} \mathrm{O}\right)-\mathrm{SiO}_{2}$ diagram into following three groups: alkali rock series, high alumina basalt series and tholeiite series. Recently many active discussions have presented on Kuno's classification (Aoki and Ito, 1968; Kurasawa, 1968; Aoki, 1968; Kuno, 1968; Shuto, 1969; Yagi, 1969). However, at present, Kuno's classification seems to 


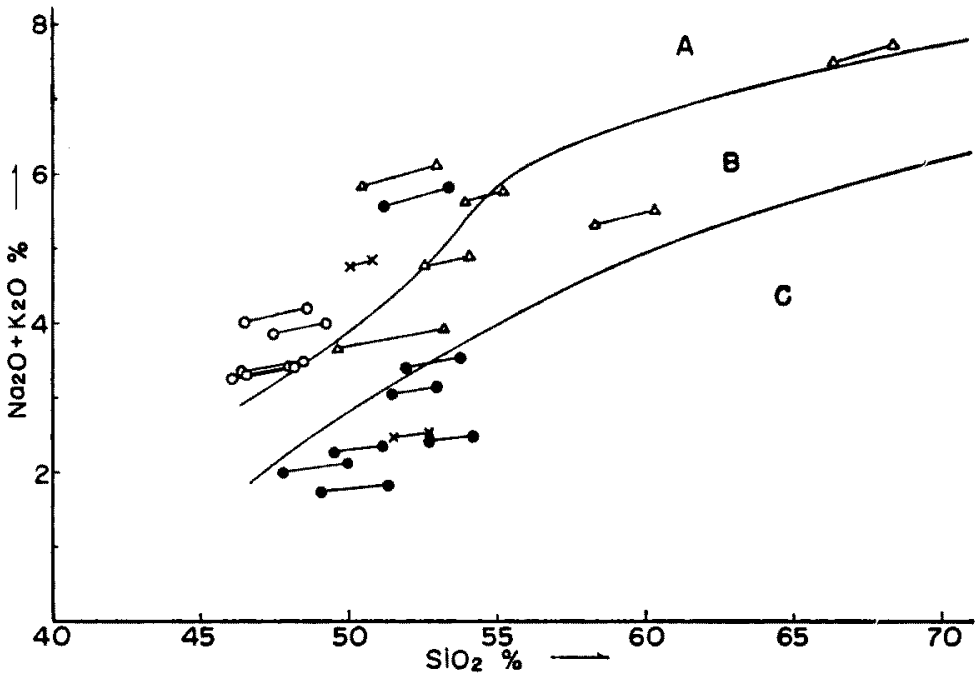

Fig. 3. $\left(\mathrm{Na}_{2} \mathrm{O}+\mathrm{K}_{2} \mathrm{O}\right)-\mathrm{SiO}_{2}$ diagram of Paleozoic volcanic rocks from the Southern Kitakami mountainland.

$A$; alkali rock series, $B$; high-alumina basalt series, $C$; tholeiite series after Kuno (1966).

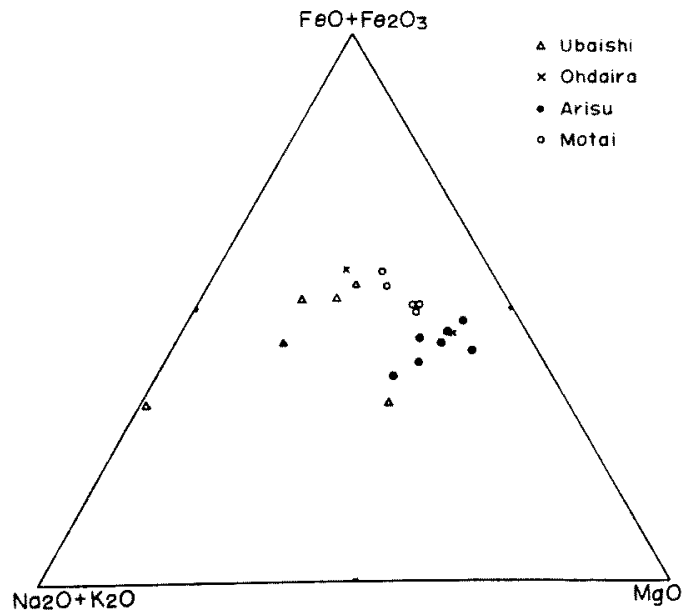

Fig. 4. AFM diagram of Paleozoic volcanic rocks from the Southern Kitakami mountainland. 


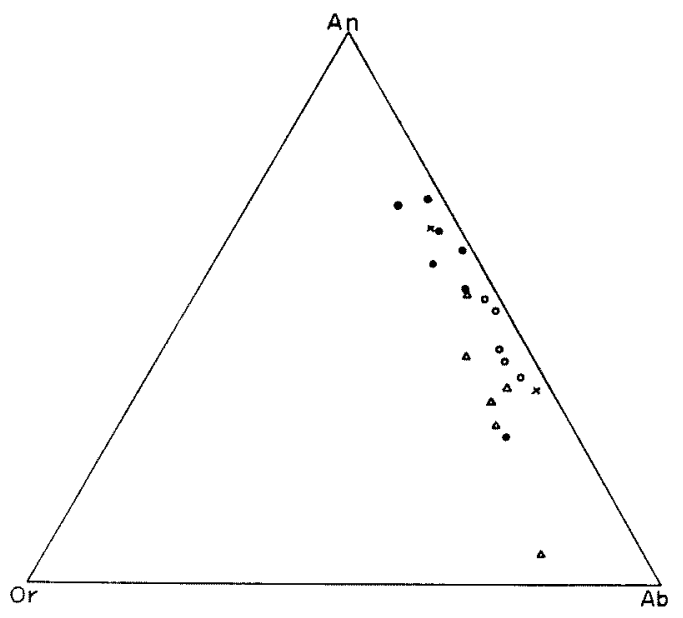

Fig. 5. Normative An-Ab-Or diagram of Paleozoic volcanic rocks from the Southern Kitakami mountainland.

be most appropriate to consider the nature of parent magmas of the Paleozoic volcanism. Volcanic rocks of various formations in the Kitakami mountainland are plotted on Kuno's $\mathrm{Al}_{2} \mathrm{O}_{3}-\left(\mathrm{Na}_{2} \mathrm{O}+\mathrm{K}_{2} \mathrm{O}\right)-\mathrm{SiO}_{2}$ diagram (Fig.2). Since Paleozoic volcanic rocks contain generally much more $\mathrm{H}_{2} \mathrm{O}$ than the original rocks, the chemical analyses are recalculated to $100 \%$ excluding $\mathrm{H}_{2} \mathrm{O} \pm$. The plots of $\mathrm{Na}_{2} \mathrm{O}+\mathrm{K}_{2} \mathrm{O}$ against $\mathrm{SiO}_{2}$ of the analysed rocks on Kuno's (1966) diagram are also shown in Fig.3. The two kinds of plots in Fig.3, namely the value of Table 3 and recalculated anhydrous value, of each rock are connected with a tie line. As shown in these figures, the volcanic rocks of each formation have their own confined fields of compositional variation, which do not so widely overlap each other. The data of the Motai Group except schistose and tuffaceous rocks are quoted from Kanisawa (1964). The rocks of the Motai Group fall in the alkali rock field, whereas those of the Arisu and the Ohdaira Formations in the tholeiite basalt field, and those of the Ubaishi Formation in the high-alumina basalt field. A few exceptions in the Arisu, Ohdaira and Ubaishi Formations fall in the alkali rock field. MgO$\left(\mathrm{FeO}+\mathrm{Fe}_{2} \mathrm{O}_{3}\right)-\left(\mathrm{Na}_{2} \mathrm{O}+\mathrm{K}_{2} \mathrm{O}\right)$ diagram also reveals that the rocks of each formation fall into their own field as shown in Fig.4. The rocks of the Motai Group have high iron content in spite of low $\mathrm{SiO}_{2}$ content, while those of the Arisu Formation are rather rich in $\mathrm{MgO}$, and those of the Ubaishi Formation have a wide range of differentiation process. Normative An-Ab-Or diagram of various rocks also shows confined area for each formation as shown in Fig.5. 
Normative $\mathrm{Ab}$ is high in rocks of the Motai Group, whereas low in those of the Arisu Formation. Those of the Ubaishi Formation have wide range of normative An-Ab. Normative Or is rather poor in those of each formation. It is noticeable that the tholeitic rocks of the Arisu Formation are rich in MgO and poor in alkalies, and these tholeiitic rocks similar in composition have not been found in Cenozoic volcanic rocks in Japan. The rocks similar in composition to those of the Arisu Formation have been described at Taos Area, northern New Mexico, U.S.A. as olivine-tholeite erupted in latest Pliocene time by Aoki (1967).

In the following the chemical characteristics of rocks of this district will be compared with those of the Paleozoic rocks of another districts in Japan. According to Tanaka (1970), geosynclinal volcanic rocks from the Paleozoic Chichibu group in central Japan mostly fall within the range of basaltic rocks, being rich in $\mathrm{TiO}_{2}, \mathrm{FeO}$ and $\mathrm{Na}_{2} \mathrm{O}$ and poor in $\mathrm{K}_{2} \mathrm{O}$, and these rocks belong to alkali basalt and high-alumina basalt. Tanaka also concluded that these rocks have petrochemical characteristics similar to abyssal basalts. Hashimoto, Kashima and Saito (1970) revealed that the Paleozoic greenstones from the two selected areas of southwest Japan are either alkali basalt or tholeiite but not high-alumina basalt, and that the composition of these rocks would have different in each formation. Moreover, Hashimoto et al. say that some greenstones from the Chichibu belt are tholeiitic and similar to abyssal tholeiite in that they are poor in $\mathrm{K}_{2} \mathrm{O}$ and rich in $\mathrm{CaO}$, though $\mathrm{SiO}_{2}$ and $\mathrm{TiO}_{2}$ contents are somewhat lower in the greenstones than in the typical abyssal

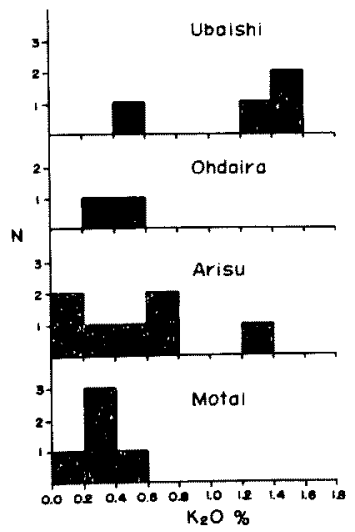

Fig. 6. Frequency distributions of $\mathrm{K}_{2} \mathrm{O}$ in basaltic rocks from various formations in the Southern Kitakami mountainland. 
tholeiite, thus the basalt magmas which erupted in the Upper Paleozoic geosynclinal basins of Southwest Japan might have been essentially of oceanic character.

In the abyssal basalts, there are remarkable characteristics that they are poor in $\mathrm{K}_{2} \mathrm{O}$ (Engel, Engel and Havens, 1965; Nicholls, 1965; Miyashiro, Shido and Ewing, 1969) and have narrow $\mathrm{SiO}_{2}$ range $(48 \sim 51 \%)$. It is shown from the data of this study that the chemical characteristics of major elements of rocks in the Kitakami mountainland differ clearly from those of Southern and Central Japan. Frequencies of $\mathrm{K}_{2} \mathrm{O}$ content of basaltic rocks (Differentiation Index $<50, \mathrm{SiO}_{\mathbf{2}}<\mathbf{5 5} \%$ ) in various formations in the district are shown in Fig.6. Range of $\mathrm{K}_{2} \mathrm{O}$ content of the rocks from the Motai Group is limited to less than $0.6 \%$ and maximum frequency is $0.2 \sim 0.4 \%$ although they belong to alkali rock series, and those of the Arisu Formation and the Ubaishi Formation are $0 \sim 1.4 \%$ and $0.4 \sim 1.6 \%$ respectively. These facts show that the volcanic rocks of the Motai Group poor in $\mathrm{K}_{2} \mathrm{O}$, rich in $\mathrm{TiO}_{2}$ and narrow $\mathrm{SiO}_{2}$ range $(48 \sim 49 \%$ as water free) are similar to those of Central Japan, but may not be abyssal basalt because they belong to alkali rock series, and show those of the lower Carboniferous and Permian formations in the Kitakami mountainland are rich in $\mathrm{K}_{2} \mathrm{O}$ and poor in $\mathrm{TiO}_{2}$ and also may not be oceanic. However, there are differences between rocks of the pre-upper Devonian Motai Group and those of the post Carboniferous with respect to $\mathrm{K}_{2} \mathrm{O}$ and $\mathrm{TiO}_{2}$ contents and $\mathrm{SiO}_{2}$ range. These differences are very important to consider the characters of the Honshu geosyncline in the Silurian to Devonian and the Chichibu geosyncline in the Upper Devonian to Permian (Onuki, 1969) in the Kitakami mountainland.

\section{SUMMARY}

Petrographical and chemical studies of the Paleozoic volcanic rocks in the Kitakami mountainland were carried out. The rocks from the lower Carboniferous show the assemblage of greenschist facies and contain secondary albitized low-temperature form plagioclase. The Permian volcanic rocks have remained in the grade lower than greenschist faceis, having primary hightemperature form plagioclase.

Chemically, volcanic rocks of the pre-Upper Devonian Motai Group belong to alkali basalt, those of the Arisu Formation in the lower Carboniferous belong to tholeiite and those of the Ubaishi Formation in the Permian belong to high-alumina basalt. Volcanic rocks of the post Carboniferous in the district are rather rich in $\mathrm{K}_{2} \mathrm{O}$ and poor in $\mathrm{TiO}_{2}$, and have no oceanic character. 


\section{APPENDIX; PETROGRAPHIC DESCRIPTIONS OF ANALYSED ROGKS}

Clinopyroxene-olivine (?) basalt. Loc., South of Sasanohora, Sumida-cho, Iwate Pref. Specimen No. 69729-5.Massive and greyish in naked eye. The rock contains abundant relic clinopyroxene $\left(\beta=1.694,2 \mathrm{Vz}=52^{\circ}\right)$ and groundmass plagioclase. Chlorite and iddingsite after olivine (?) are observed. Secondary minerals are actinolite, chlorite, sericite, leucoxene and epidote.

2. Olivine(?)-clinopyroxene basalt. Loc., East of Komata, Sumida-cho, Iwate Pref. Specimen No. 69730-3. Massive, greyish green in naked eye. Relic clinopyroxene $\left(\beta=1.697,2 \mathrm{Vz}=50^{\circ} \sim 47.5^{\circ}, c \wedge Z=41^{\circ}\right)$ and plagioclase are primary minerals. Groundmass minerals are almost completely altered to secondary minerals. Chlorite and epidote pseudomorphs after olivine (?) are present. Other secondary minerals are actinolite $\left(2 \mathrm{Vz}=76^{\circ}\right)$, leucoxene, calcite and quartz.

3. Clinopyroxene basalt. Loc., Northwest of Komata, Sumida-cho, Iwate Pref. Specimen No. 69090601. The rock is greyish white, fine and compact in naked eye. Intergranular texture. It consists of relic clinopyroxene $(\beta=$ 1.696, $\left.2 \mathrm{Vz}=54^{\circ} \sim 45.5^{\circ}, \quad c \wedge \mathrm{Z}=38.5\right)$, secondary actinolite $\left(2 \mathrm{Vx}=74^{\circ}\right)$, chlorite, epidote, leucoxene, albitic plagioclase and quartz.

4. Olivine (?)-clinopyroxene basalt. Loc., Komata, Sumida-cho, Iwate Pref. Specimen No. 69090607. The rock is greyish green and massive in naked eye. Subophitic to intergranular texture consisting of relic clinopyroxene $\left(\beta=1.696, \quad 2 \mathrm{Vz}=45^{\circ} \sim 52^{\circ} . \quad \mathrm{c} \wedge \mathrm{Z}=40^{\circ}\right)$ and albitized plagioclase $\left(\mathrm{An}_{5}\right.$ from $\mathrm{n}_{1} \min =1.630, \mathrm{n}_{2} \max =1.640 ; \mathrm{An}_{4 \sim 7}$ and ord. deg. $=0.9-1.2$ from U-stage method). Chlorite pseudomorphs after olivine (?) are observed. Actinolite $\left(2 \mathrm{Vz}=76^{\circ}, \mathrm{c} \wedge \mathrm{Z}=15.5^{\circ}\right)$, chlorite and calcite are the secondary minerals. 5. Clinopyroxene basalt. Loc., Shimokashiwari, Sumida-cho, Iwate Pref. Specimen No. 69913-1. Pale greenish grey rock having phenocrystic clinopyroxene. Relic clinopyroxene $\left(\beta=1.703,2 \mathrm{Vz}=54^{\circ} \sim 52^{\circ}, c \wedge Z=37.5^{\circ}\right)$, altered plagioclase, epidote, actinolite $\left(2 \mathrm{Vx}=80^{\circ} \sim 84^{\circ}, \mathrm{c} \wedge \mathrm{Z}=17^{\circ}\right)$, chlorite, leucoxene and sericite are constituents.

6. Clinopyroxene basalt. Loc., West of Kashiwari tunnel, Sumida-cho, Iwate Pref. Specimen No. 69913-3. Pale greenish grey. Intergranular texture. Relic clinopyroxene $\left(\beta=1.703,2 \mathrm{Vz}=47^{\circ}-43^{\circ}, \mathrm{c} \wedge \mathrm{Z}=39^{\circ}\right)$, albitized plagioclase. secondary actinolite, chlorite, epidote, quartz and leucoxene are constituents.

7. Olivine (?)-clinopyroxene basalt. Loc., Shizu, Sumida-cho, Iwate Pref. Specimen No. 69913-6. Pale greyish green. Relic phenocrystic clinopyroxene $\left(\beta=1.698,2 \mathrm{Vz}=56^{\circ} \sim 52^{\circ}\right)$ and groundmass lath plagioclase are primary minerals. Secondary actinolite, chlorite, epidote, leucoxene and quartz are observed. 
8. Contact metamorphosed basalt. Loc., Midstream of the Otsubo sawa, Rikuzen-Takada city, Iwate Pref. Specimen No. OD-1. Dark green and compact rock. Prinary plagioclase and contact recrystallized actinolitic amphibole, biotite and leucoxene are constituents.

9. Contact metamorphosed basalt. Loc., Midstream of the Otsubo sawa, Rikuzen-Takada city, Iwate Pref. Specimen No. OD-2. Dark green. Primary plagioclase $\left(A n_{71-75}\right)$ and contact recrystlallized actinolitic amphibole, biotite and quartz are constituents.

10. Andesite. Loc., Hatasawa-bashi, East of Ubaishi, Sumida-cho, Iwate Pref. Specimen No. \$69072602. The rock is greyish green. It consists from partly sericitized phenocrystic plagioclase $\left(\mathrm{An}_{85 \sim 63}\right)$, chlorite and leucoxenized iron ore. Mafic minerals are completely altered to chlorite.

11. Andesite. Loc., The top of Taneyama, Sumida-cho, Iwate Pref. Specimen No, F69082607 Dark green, hyalo-ophitic texture. Phenocrystic plagioclase $\left(\mathrm{An}_{54-47}\right)$ and groundmass lath plagioclase are considerably fresh. Mafic minerals are completely altered to chlorite, epidote, calcite and leucoxene. A few amygdules are filled with calcite.

12. Andesite. Loc., Ubaishi, Sumida-cho, Iwate Pref. Specimen No. F69072601. Dark green, hyalo-ophitic texture. Phenocrystic plagioclase $\left(A n_{58-52}\right)$ and groundmass lath plagioclase are rather fresh. Mafic minerals are recrystallized into actinolite, chlorite and leucoxene.

13. Clinopyroxene andesite. Loc., ESE of Ubaishi, Sumida-cho, Iwate Pref. Specimen No. F69072606. Greyish green, pilotaxitic texture, composed of relic clinopyroxene phenocryst, groundmass plagioclase, secondary chlorite, actinolite, leucoxene and iron ore. Clinopyroxene is surrounded by small amount of actinolite.

14. Hornblende-clinopyroxene andesite. Loc., Hatasawa-bashi, East of Ubaishi, Sumida-cho, Iwate Pref. Specimen No. F69072605. The rock is pale greyish green, and composed of phenocrystic clinopyroxene, hornblende ( $\mathrm{X}=$ brownish vellow, $\mathrm{Z}=$ brown), plagioclase $\left(\mathrm{An}_{63 \sim 52}\right)$, and of groundmass plagioclase, secondary chlorite, calcite and leucoxene.

15. Dacite. Loc., South of Ubaishi, Sumida-cho, Iwate Pref. Specimen No. F69072408. The rock is pale greenish grey, and composed of small amounts of phenocrystic plagioclase $\left(\mathrm{An}_{24}\right)$, groundmass plagioclase showing intersertal texture, and secondary chlorite and quartz.

\section{REFERENGES}

Aoki, H. and Ito, M. (1968), Rocks of the Oceanic region-I. High-alumina basalts-, Earth Sci., 22, 24 31 (in Japanese with English abstract). Aoki, K. (1967), Petrology and petrochemistry of latest Pliocene olivine- 
tholeiites of Taos Area, northern New Mexico, U.S.A., Contr. Min. Petr., 14, 190 203 .

- (1968), High-alumina basalts, Earth Sci., 22, 300-304.(in Japanese)

Dickinson, W.R. (1962), Petrology and diagenesis of Jurassic andesitic strata in central Oregon, Am. Jour. Sci., 260, 481 $\sim 500$.

Engel, A.E.]., Engel, C.G. and Havens, R.G. (1965), Chemical characteristics of oceanic basalts and the Upper Mantle, Bull. Geol. Soc. Am., 76, $719 \sim 734$.

Hashimoto, M. Kashima, N. and Saito, Y. (1970), Chemical composition of Paleozoic greenstones from two areas of Southwest Japan, Jour. Geol. Soc. Japan, 76, 463 476.

Hess, H.H. (1949), Chemical composition and optical properties of common clinopyroxenes, Am. Min., 34, 621 666 .

Jolly, W.T. (1970), Zeolite and prehnite-pumpellyite facies in South Central Puerto Rico, Contr. Min. Petr., 27, 204 224.

Kanisawa, S. (1964), Metamorphic rocks of the Southwestern part of the Kitakami mountainland, Japan, Sci. Rep. Tohoku Univ,, Ser. III, 9. $\quad 155 \sim 198$.

Kim, C.W. (1964), On some behaviour of plagioclase feldspars during the formation and the hydrothermal alteration of propylites, Jour. Geol. Soc. Japan, 70, 423 433 (in Japanese with English abstract).

Kuno, H. (1960), High alumina basalt, Jour. Petr., 1, 121 145.

- (1966), Lateral variation of basalt magma type across continental margins and Island Arcs, Bull. Volc., 29, 195 222.

(1968), Rocks in the oceanic region I. High alumina basalt. Discussion of paper by H.Aoki and M. Ito, Earth Sci. 22, 195 197 (in Japanese).

Kurasawa, H. (1968), Origin of basaltic magma and high-alumina basalt, Earth Sci., 22, 295 299 (in Japanese).

Lidiak, E.G. (1965), Petrology of andesitic, spilitic and keratophyric flow rock, North-Central Puerto Rico, Bull. Geol. Soc. Am., 76, 57 88.

Martin, R.F. (1969), The hydrothermal synthesis of low-albite, Contr. Min. Petr., 23, 323 339.

Miyashiro, A., Shido, F. and Ewing, M. (1969), Diversity and origin of abyssal tholeiite from the Mid-Atlantic ridge near $24^{\circ}$ and $30^{\circ}$ North Latitude, Contr. Min. Petr., 23, 38 $\sim 52$.

Muir, I.D. (1951), The clinopyroxenes of the Skaergaard intrusion, eastern Greenland, Min. Mag., 29, 690 714 .

Murata, M. and Maiya, S. (1964), On the geologic time of the Ubaishi Formation (abs), Jour. Geol. Soc. Japan, 60, 382 (in Japanese).

Nicholls, G.D. (1965), Basalts from the deep ocean floor, Min. Mag., 34, $373 \sim 388$.

Onuki, Y. (1969), Geology of the Kitakami Massif, Northeast Japan, Tohoku Univ., Inst. Geol. Pal., Contr., no. 69, 1 239. (in Japanese with English abstract).

Shuto, K. (1969), Discussion to the papers by H. Kuno, K. Aoki and H. 
Kurasawa-with reference to the Tertiary high-alumina basalt-Earth Sci., 23, 15 19 (in Japanese)

Tanaka, T. (1970), Chemical composition of geosynclinal volcanic rocks from the Paleozoic Chichibu group in central Japan, Jour. Geol. Soc. Japan, 76, 323 335 (in Japanese with English abstract).

Uruno, K. (1963), Optical study on the ordering degree of plagioclase feldspars, Sci. Rep. Tohoku Univ., Ser. III, 8, 171 220.

Yagi, K. (1969), On the problems of high-alumina basalt, Earth Sci., 23, 149 152 (in Japanese).

Yoshitani, A. (1970), Studies on the Green Tuff formation in the Futamata region nearby Toyoha Mine, Southeast Hokkaido, Japan, Memoir. Fac. Sci. Kyoto Univ., Ser. B, 36, 87 178.

\section{南部北上山地古生層中の塩基性～中性火山岩類}

$$
\text { 蟹沢聡史 }
$$

摘

要

表記地域の火山岩類について岩石学的に検討した結果，次の事实が明らかになった。す

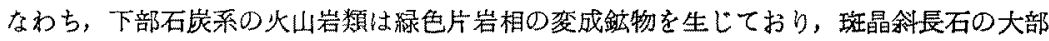
分は秩序度の高い低温型の曹長石に変っているのに刘して，二量系のそれはより変成度が 低く，斑晶斜長石はほとんど火山岩的な要素を戥存している。化学組成は，各層潄に上り 特徽があり，先上部デボン免母体層群のものは久野（1960）のアルカリ岩系に属し，下部

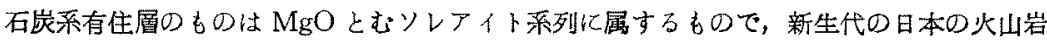
類とはや〉罣なった性質を示し，New Mexico のかんらん石ソレアイトに近いるのであ る。二畳系姥石層のものは高アルミナ去武岩系牦しており，石英安山岩質のちのまであ る。西南日本口秩父系で芫っ加つている深海ソレアイトに属する火山岩類はみられふい。 